\title{
Clinicopathological and prognostic significance of COX-2 immunohistochemical expression in breast cancer: a meta- analysis
}

\author{
Feng $\mathrm{Xu}^{1,}{ }^{*}$, Mengxin $\mathrm{Li}^{1}$, Chao Zhang ${ }^{1}$, Jianxiu Cui ${ }^{1}$, Jun Liu ${ }^{1}$, Jie $\mathrm{Li}^{1}$, Hongchuan \\ Jiang $^{1}$ \\ ${ }^{1}$ Department of Breast Surgery, Beijing Chao-Yang Hospital, Capital Medical University, Beijing, China, 100020 \\ * Co-first author
}

Correspondence to: Hongchuan Jiang, email: drjhc@sina.com

Keywords: breast cancer, COX-2, prognosis, meta-analysis

Received: July 04, $2016 \quad$ Accepted: December 12, 2016

Published: December 16, 2016

\section{ABSTRACT}

The prognostic significance of COX-2 in patients with breast cancer remains controversial. The aims of our meta-analysis are to evaluate its association with clinicopathological characteristics and prognostic value in patients with breast cancer. PubMed, EMBASE, Web of Science, the Ovid Database and Grey literature were systematically searched up to May 2016. Twenty-one studies including 6739 patients with breast cancer were analyzed. The meta-analysis indicated that the incidence difference of COX-2 expression was significant when comparing the lymph node positive group to negative group (OR $=1.76,95 \% \mathrm{CI}[1.30,2.39])$ and the tumor size $\geq 2 \mathrm{~cm}$ group to the tumor size $<2 \mathrm{~cm}$ group (OR $=1.71,95 \%$ CI $[1.22,2.39]$ ). None of other clinicopathological parameters such as the ER status, PR status, HER2 status and the vascular invasion status were associated with COX-2 overexpression. The detection of COX-2 was significantly correlated with the disease-free survival (DFS) of patients (HR $=1.58,95 \% \mathrm{CI}[1.23,2.03]$ ) and the overall survival (OS) of patients (HR $=1.51,95 \% \mathrm{CI}[1.31,1.72])$. Our meta-analysis demonstrates that the presence of high levels of COX-2 is associated with poor prognosis for breast cancer patients and predicts bigger tumor size and lymph node metastasis.

\section{INTRODUCTION}

As one of the most frequently diagnosed malignant tumor, breast cancer (BC) ranks first among female cancer deaths. In 2015, for example, approximately 234,190 new cases in the USA diagnosed with breast cancer annually, with an estimated 40,730 deaths [1]. Despite the development of surgery and adjuvant chemotherapy has significantly improved the clinical survival for BC patients over past few years, the occurrence of breast cancer is still on the rise. The prognostic factors that have been implicated include human epidermal growth factor receptor (HER2), estrogen/ progesterone receptor (ER/ $\mathrm{PR}$ ), tumor size, lymph nodes metastasis, and response to chemotherapy [2]. However, the mechanism of the clinical outcome in breast cancer patients has yet to be completely understood. Therefore, novel prognostic biomarkers and therapeutic targets are needed to be identified for the management of breast carcinoma.
Recently, research on cyclooxygenase (COX) in tumorigenesis and tumor progression has become a hotspot [3]. Apart from the newly discovered COX-3 isoform, COX-1 and COX-2 are involved in the prostanoids synthesis [4]. These isoenzymes locate in different chromosomes and differ considerably in patterns of expression and biology. Among them, COX-2 is usually undetectable in normal tissues. Various stimulating factors such as hormones, cytokines, and dysregulated oncogenes have all been shown to cause induction of COX-2 expression [5]. It is reported that COX-2 have an carcinogenic impact on various cancers, such as lung [6], oesophagus [7], breast, colorectal [8] and pancreas cancer [9].

In breast cancer, increased COX-2 expression is found in cancerous tissue compared to the corresponding paracancerous tissues [10]. Many researches have evaluated the association between $\mathrm{COX}-2$ overexpression and the prognosis of breast cancer patients. However, the findings with respect to $\mathrm{COX}-2$ expression in $\mathrm{BC}$ 
specimens are varying and sometimes conflicting. In order to clarify the question, we collected all eligible articles to determine the association between COX-2 overexpression and clinicopathological parameters/prognoses in $\mathrm{BC}$ patients.

\section{RESULTS}

\section{Study selection and characteristics}

228 relevant manuscripts were initially retrieved. After using the search strategy mentioned above, a total of 21 studies [11-31] comprising 6739 patients were considered in this meta-analysis (Figure 1). The major features and quality assessment of the 21 eligible articles were summarized in Tables 1 and 3 . The studies were conducted in 15 countries (China, Finland, Korea, Portugal, Austria, Poland, Sweden, Germany, Italy, Turkey, Brazil, Turkey, Tunisia, Norway, and the United States). Fourteen studies were performed using immunohistochemistry (IHC) method, and the remaining seven studies followed tissue microarray (TMA) method. Eleven studies evaluated the prognostic effect of COX-2 overexpression in $\mathrm{BC}$ patients. Among them, ten studies reported the overall survival(OS) of $\mathrm{BC}$ patients, and six for disease-free survival(DFS). The occurrence of COX-2 overexpression in each study ranged from $27.9 \%$ to $81.4 \%$. The cut-off values of IHC/TMA evaluation were inconsistent. Regarding different anti-COX-2 monoclonal antibodies, ten studies used clone 160112 from Cayman company, and eleven focused on others. We extracted hazard ratios and their corresponding 95\% CIs from the graphical survival curve in 5 univariable analyses and reported them directly in 6 multivariate analyses. Moreover, none of the patients received neo-adjuvant chemotherapy prior to surgery.

\section{Association of COX-2 overexpression with clinicopathological features}

The relationship between COX-2 positivity and tumor size, lymph node metastasis, ER status, PR status, HER2 status, and vascular invasion status was considered in our meta-analysis. The pooled ORs using random-effect model were 1.71 (95\% CI: $\left.1.22-2.39, I^{2}=56 \% ; P=0.03\right)$, 1.76 (95\% CI: $\left.1.30-2.39, I^{2}=66 \% ; P=0.0004\right), 1.37$

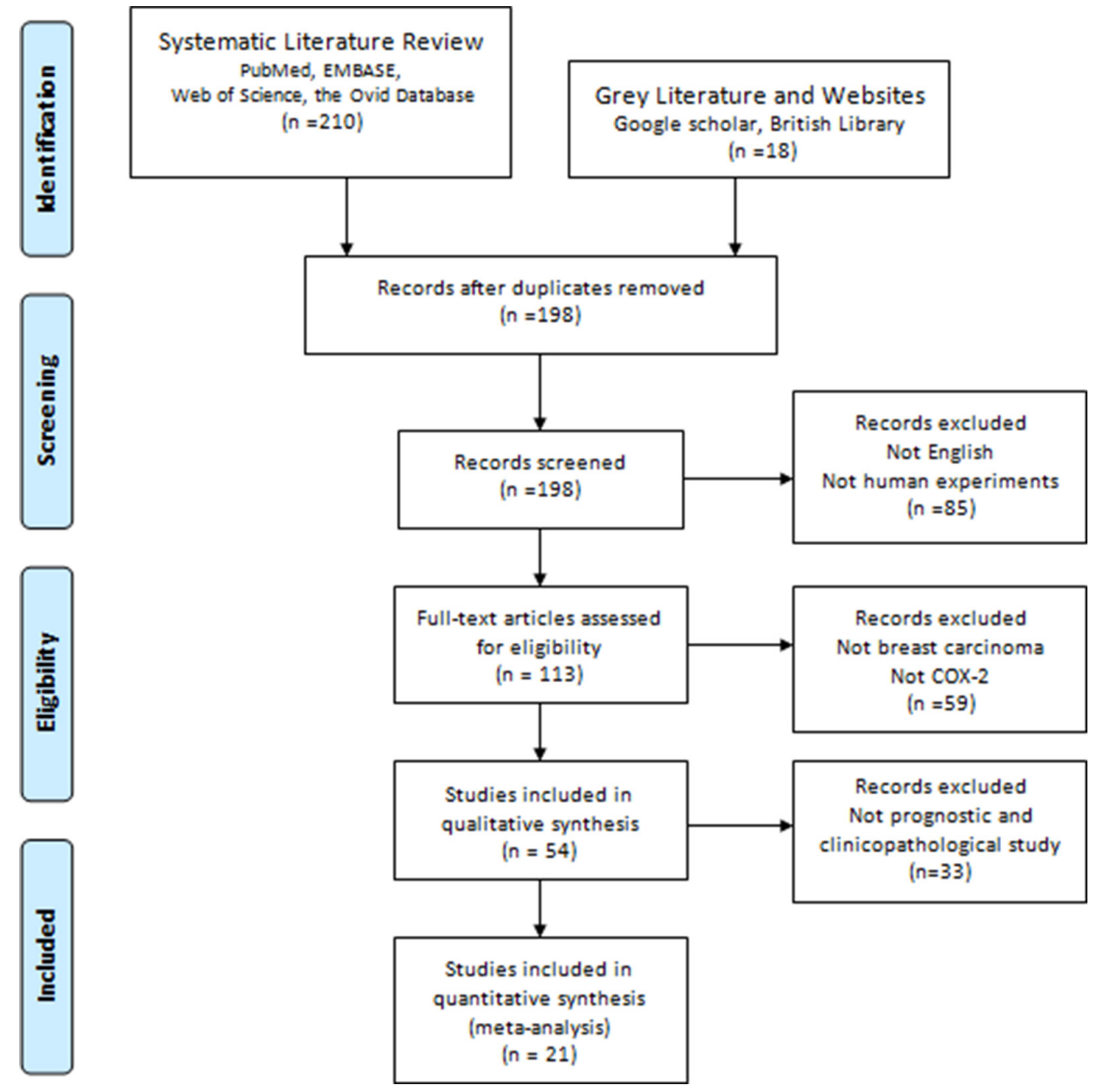

Figure 1: PRISMA flow chart of the literature search. 
Table 1: Main characteristics and results of the enrolled studies

\begin{tabular}{|c|c|c|c|c|c|c|c|c|c|c|}
\hline $\begin{array}{l}\text { Authors } \\
\text { [ref] }\end{array}$ & Year & $\begin{array}{c}\text { Number } \\
\text { of } \\
\text { patients }\end{array}$ & Country & $\begin{array}{l}\text { Detection } \\
\text { Method }\end{array}$ & $\begin{array}{c}\text { Cut-off } \\
\text { (positive/High } \\
\text { expression) }\end{array}$ & $\begin{array}{c}\text { Antibody } \\
\text { For Cox-2 } \\
\text { staining }\end{array}$ & $\begin{array}{c}\text { Analysis } \\
\text { method }\end{array}$ & $\begin{array}{c}\text { HR For } \\
\text { Survival } \\
(95 \% \text { CI })\end{array}$ & $\begin{array}{c}\text { Follow up } \\
\text { (months) }\end{array}$ & $\begin{array}{c}\text { Quality } \\
\text { assessment } \\
\text { (NOS) }\end{array}$ \\
\hline Costa C [11] & 2002 & 46 & Portugal & IHC & NA (8) & NA & Univariable & \begin{tabular}{|c|} 
Survival curve \\
DFS: 4.22 \\
$(0.26-68.49)$ \\
\end{tabular} & $>25$ & 7 \\
\hline Ristimaki A [12] & 2002 & 1576 & Finland & TMA & $\begin{array}{c}\text { score }>1 \\
(592)\end{array}$ & \begin{tabular}{|c|}
$\begin{array}{c}\text { Clone } 160112, \\
\text { Cayman }\end{array}$ \\
\end{tabular} & NA & NA & NA & 8 \\
\hline Denkert C [13] & 2003 & 221 & Germany & IHC & $\begin{array}{c}\text { Score }>6 \\
(80)\end{array}$ & $\begin{array}{c}\text { Clone } 160112 \\
\text { Cayman }\end{array}$ & Mutivariable & $\begin{array}{c}\text { Reported } \\
\text { DFS: } 1.90 \\
(1.00-3.61) \\
\text { OS:1.14 } \\
(0.67-1.93) \\
\end{array}$ & NA & 8 \\
\hline Spizzo G [14] & 2003 & 212 & Austria & IHC & $\begin{array}{c}\text { Score }>4 \\
\quad(103)\end{array}$ & $\begin{array}{c}\text { Clone } 160112 \\
\text { Cayman }\end{array}$ & Univariable & $\begin{array}{c}\text { Survival curve } \\
\text { DFS: } 1.28 \\
(0.79-2.07) \\
\text { OS: } 1.46 \\
(0.90-2.38) \\
\end{array}$ & 126 & 8 \\
\hline Wulfing P [15] & 2003 & 192 & Germany & TMA & $\begin{array}{c}\text { score }>1 \\
\quad(78)\end{array}$ & $\begin{array}{c}\text { Clone } 160112, \\
\text { Cayman }\end{array}$ & Univariable & $\begin{array}{c}\text { Survival curve } \\
\text { OS: } 1.56 \\
(0.87-2.78) \\
\text { DFS: } 1.26 \\
(0.73-2.17)\end{array}$ & $71(0-110)$ & 7 \\
\hline John K [16] & 2004 & 23 & America & $\mathrm{IHC}$ & $\begin{array}{c}\geq 75 \% \\
(15)\end{array}$ & \begin{tabular}{|} 
Clone ALX- \\
804-112-C050, \\
Alexis \\
Biochemicals
\end{tabular} & Univariable & $\begin{array}{c}\text { Survival curve } \\
\text { OS: } 2.29 \\
(0.30-17.48) \\
\text { DFS: } 2.08 \\
(0.31-13.96) \\
\end{array}$ & 48 & 6 \\
\hline Surowiak P [17] & 2005 & 102 & Poland & $\mathrm{IHC}$ & $\begin{array}{l}>10 \% \\
(46)\end{array}$ & $\begin{array}{c}\text { Clone } 160112 \\
\text { Cayman }\end{array}$ & Univariable & $\begin{array}{c}\text { Survival curve } \\
\text { OS:3.81 } \\
(1.06-13.69)\end{array}$ & 81 & 8 \\
\hline $\begin{array}{l}\text { Gunnarsson C } \\
{[18]}\end{array}$ & 2006 & 284 & Sweden & TMA & NA (234) & $\begin{array}{c}\text { Clone } 160112, \\
\text { Cayman }\end{array}$ & NA & NA & NA & 6 \\
\hline Park K [19] & 2006 & 178 & Korea & TMA & $\begin{array}{l}>80 \% \\
(70)\end{array}$ & $\begin{array}{c}\text { Clone } 160112 \\
\text { Cayman }\end{array}$ & Mutivariable & $\begin{array}{c}\text { Reported } \\
\text { DFS: } 1.91 \\
(1.24-2.94) \\
\text { OS: } 1.73 \\
(1.16-2.58) \\
\end{array}$ & $42(1-60)$ & 7 \\
\hline Narssar A [20] & 2007 & 43 & America & TMA & $\begin{array}{l}\text { Score }>2 \\
\quad(35)\end{array}$ & $\begin{array}{c}\text { Clone } 160112, \\
\text { Cayman }\end{array}$ & NA & NA & NA & 5 \\
\hline $\begin{array}{l}\text { Zerkowski MP } \\
\text { [21] }\end{array}$ & 2007 & 669 & America & TMA & $\begin{array}{l}\text { score }>19.3 \\
\quad(294)\end{array}$ & $\begin{array}{c}\text { Clone } 160112, \\
\text { Cayman }\end{array}$ & Mutivariable & $\begin{array}{c}\text { Reported } \\
\text { OS: } 1.66 \\
(1.12-2.46) \\
\end{array}$ & $\begin{array}{c}106 \\
(2-636)\end{array}$ & 6 \\
\hline Zhang XH [22] & 2008 & 70 & China & IHC & $>5 \%(46)$ & Zymed & NA & NA & NA & 7 \\
\hline Glynn SA [23] & 2010 & 238 & America & $\mathrm{IHC}$ & $\begin{array}{c}\text { Score }>3 \\
\quad(90)\end{array}$ & $\begin{array}{l}\text { Clone 33, } \\
\text { BD }\end{array}$ & Mutivariable & $\begin{array}{c}\text { Reported } \\
\text { OS:1.82 } \\
(1.07-3.10) \\
\end{array}$ & $\begin{array}{c}68 \\
(12-166)\end{array}$ & 8 \\
\hline Miglietta A [24] & 2010 & 91 & Italy & IHC & $\begin{array}{c}\text { Score }>4 \\
(64)\end{array}$ & Cayman & NA & NA & NA & 7 \\
\hline $\begin{array}{l}\text { Rozenowicz RD } \\
{[25]}\end{array}$ & 2010 & 41 & Brazil & $\mathrm{IHC}$ & $\begin{array}{c}\text { Score }>1 \\
\quad(23)\end{array}$ & $\begin{array}{c}\text { 3362-100, } \\
\text { Biovision }\end{array}$ & NA & NA & NA & 6 \\
\hline Barisik NO [26] & 2011 & 62 & Turkey & IHC & $\begin{array}{l}\text { Score } \geq 4 \\
\quad(47)\end{array}$ & $\begin{array}{c}\text { Clone SP392, } \\
\text { DAKO }\end{array}$ & NA & NA & NA & 6 \\
\hline Ciris IM [27] & 2011 & 51 & Turkey & IHC & $\begin{array}{l}\text { Score } \geq 2 \\
\quad(30)\end{array}$ & $\begin{array}{l}\text { Clone SP21, } \\
\text { Labvision }\end{array}$ & NA & NA & NA & 7 \\
\hline $\begin{array}{l}\text { Holmes MD } \\
{[28]}\end{array}$ & 2011 & 2001 & America & TMA & $\begin{array}{c}\text { Score } \geq 1 \\
(560)\end{array}$ & $\begin{array}{c}\text { Clone SP21, } \\
\text { Labvision }\end{array}$ & Mutivariable & $\begin{array}{c}\text { Reported } \\
\text { OS:1.37 } \\
(1.13-1.67)\end{array}$ & $>240$ & 8 \\
\hline
\end{tabular}




\begin{tabular}{|l|c|c|c|c|c|c|c|c|c|c|}
\hline Sondes KC [29] & 2011 & 83 & Tunisia & IHC & $\begin{array}{c}\text { Score } \geq 4 \\
(46)\end{array}$ & $\begin{array}{c}\text { Clone M-19, } \\
\text { Santa cruz }\end{array}$ & Mutivariable & $\begin{array}{c}\text { Reported } \\
\text { OS:6.4 } \\
(1.31-31.41)\end{array}$ & $3-120$ & 7 \\
\hline Dhakal HP [30] & 2012 & 468 & Norway & IHC & $\begin{array}{c}\text { Score } \geq 4 \\
(292)\end{array}$ & $\begin{array}{c}\text { Clone SP-21, } \\
\text { Thermo Fisher }\end{array}$ & NA & NA & 8 \\
\hline Kargi A [31] & 2013 & 88 & Turkey & IHC & $>10 \%(41)$ & $\begin{array}{c}\text { Clone 4H-12, } \\
\text { Abcam }\end{array}$ & NA & NA & $\begin{array}{c}74.2 \\
(1.9-93.7)\end{array}$ \\
\hline
\end{tabular}

HR: hazard ratio; CI: confidence interval; NOS: New-castle-Ottawa; IHC: immunohistochemistry; TMA: tissue microarray; NA: not available.

(95\% CI:0.83-2.28, $\left.I^{2}=87 \% ; P<0.00001\right), 1.50$ (95\% CI: $\left.0.85-2.63, I^{2}=87 \% ; P<0.00001\right), 1.49$ (95\% CI: 0.97-2.30, $\left.I^{2}=69 \% ; P=0.0004\right)$, and 1.57 (95\% CI: 0.88-2.80, $\left.I^{2}=56 \% ; P=0.06\right)$ respectively (Figure 2$)$. We found that increased COX-2 expression was significantly correlated with positive lymph node metastasis and bigger tumor size but not with ER status, PR status, HER2 status and the vascular invasion of breast carcinoma. In order to detect the source of heterogeneity among studies, we conducted "metareg" command using variables such as publication date, country, antibody catalog and detection method. The results showed that no variable included in the meta regression contributed to the heterogeneity.

\section{Association of COX-2 overexpression with survival outcome}

Ten studies evaluated the relationship between COX-2 overexpression and OS of BC patients. The pooled HR with fixed effect model was 1.51 (95\% CI: 1.31-1.72;
$I^{2}=0 \% ; P=0.48$ ) (Figure 3 ), indicating high COX-2 expression significantly predicts poor OS of patients with breast cancer. To explore the heterogeneity with regard to OS, we performed subgroup analysis according to detection method, antibody catalog and analysis method (Table 2). Regarding diverse detection methods, subgroup analyses using a fixed effect model showed that increased COX-2 predicted an unfavorable prognosis by IHC (HR:1.60, 95\% CI:1.21-2.13, $P=0.24)$ and TMA method (HR:1.48,95\% CI: $1.27-1.72, P=0.68$ ). When subgroup analyses were stratified by the statistical analysis methodology, our results demonstrated that higher COX-2 expression was significantly correlated with poor OS both by univariable analysis (HR: 1.63, 95\% CI: 1.14-2.31, $P=0.57$ ) and multivariable analysis (HR: $1.48,95 \%$ CI: $1.28-1.71, P=0.28)$. Considering different antiCOX-2 monoclonal antibodies, COX-2 overexpression was predictive of worse OS for the studies applying clone 160112 (HR: $1.57,95 \%$ CI: $1.28-1.93, P=0.60)$ and other antibodies (HR: $1.45,95 \% \mathrm{CI}: 1.21-1.73, P=0.20$ ). It
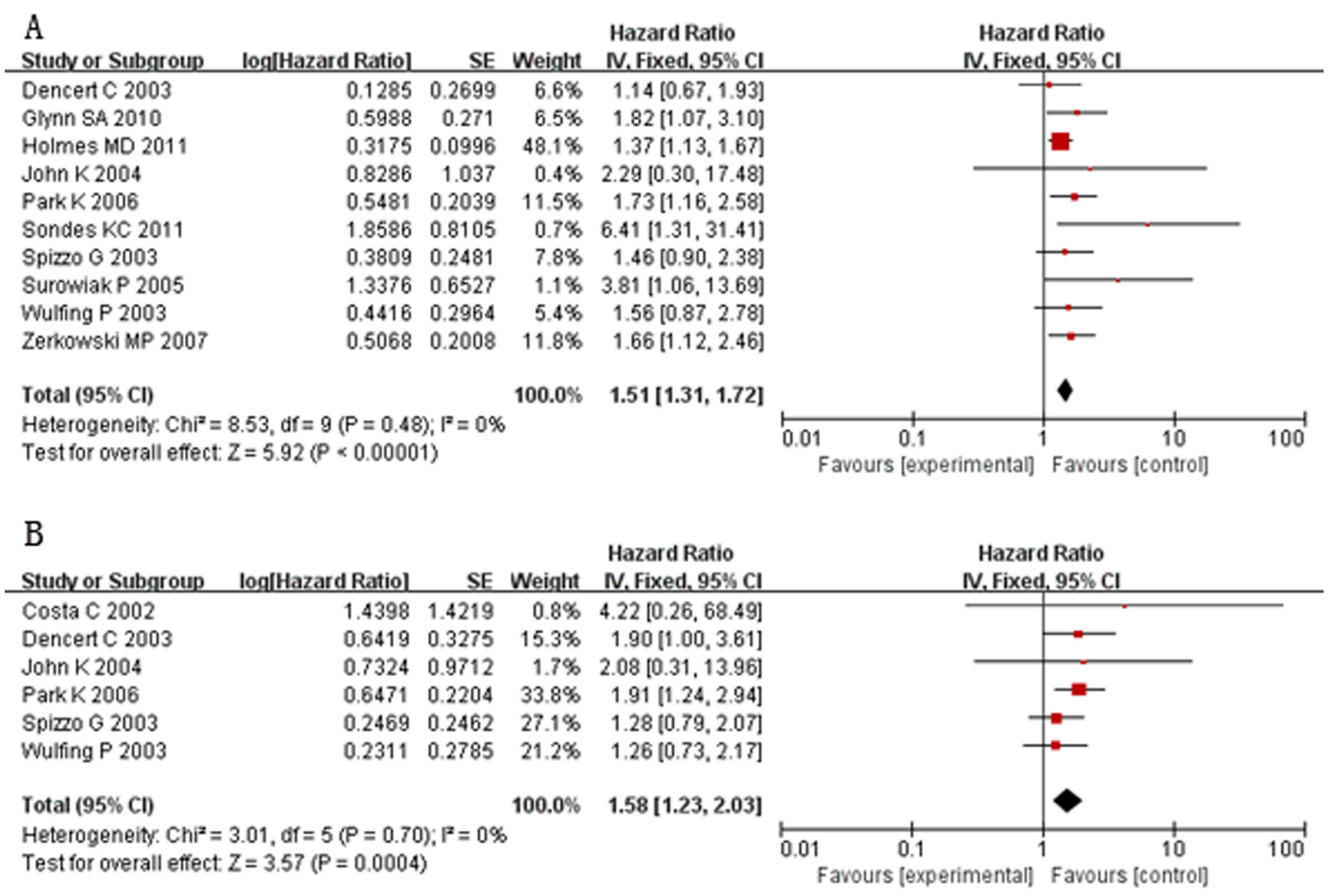

Figure 2: Forest plots of studies evaluating hazard ratios (HRs) of COX-2 for overall survival (A) and disease-free survival (B) with fixed effect model. 
Table 2: Meta analysis results

\begin{tabular}{|c|c|c|c|c|c|}
\hline Outcome & Variables & $\begin{array}{l}\text { Number } \\
\text { of studies }\end{array}$ & $\begin{array}{c}\text { Number of } \\
\text { patients }\end{array}$ & $\begin{array}{c}\mathrm{HR}_{\mathrm{FEM}} \\
\left(\mathbf{9 5 \%} \mathrm{CI}_{\mathrm{FEM}}\right)\end{array}$ & $P_{\mathrm{FEM}}$ \\
\hline \multirow[t]{10}{*}{ OS } & ALL & 10 & 3919 & $1.51(1.31-1.72)$ & 0.48 \\
\hline & Detection method & & & & \\
\hline & IHC & 6 & 879 & $1.60(1.21-2.13)$ & 0.24 \\
\hline & TMA & 4 & 3040 & $1.48(1.27-1.72)$ & 0.68 \\
\hline & Analysis method & & & & \\
\hline & Univariable & 4 & 529 & $1.63(1.14-2.31)$ & 0.57 \\
\hline & Mutivariable & 6 & 3390 & $1.48(1.28-1.71)$ & 0.28 \\
\hline & Antibody-catalog & & & & \\
\hline & Clone 160112 & 6 & 1574 & $1.57(1.28-1.93)$ & 0.60 \\
\hline & Others & 4 & 2345 & $1.45(1.21-1.73)$ & 0.20 \\
\hline
\end{tabular}

HR: hazard ratio; CI: confidence interval; IHC: immunohistochemistry; TMA: tissue microarray; OS: overall survival; FEM: fixed effect model.

indicated that no variable mentioned above contributed to the heterogeneity in the results.

A total of six studies assessed COX-2 immunoexpression and correlated it to DFS. The combined HR with fixed effect model was 1.58 (95\% CI: 1.23-2.03) given the absence of heterogeneity. Similarly, the overexpression of COX-2 was also significantly associated with poor DFS in breast cancer. Due to limited studies, no subgroup analysis regarding DFS was identified in the meta analysis.

\section{Publication bias and sensitivity analysis}

Our statistical results showed that there was no evidence of publication bias in the funnel plot as it seemed to be symmetrical (Figure 4). Sensitivity analysis was
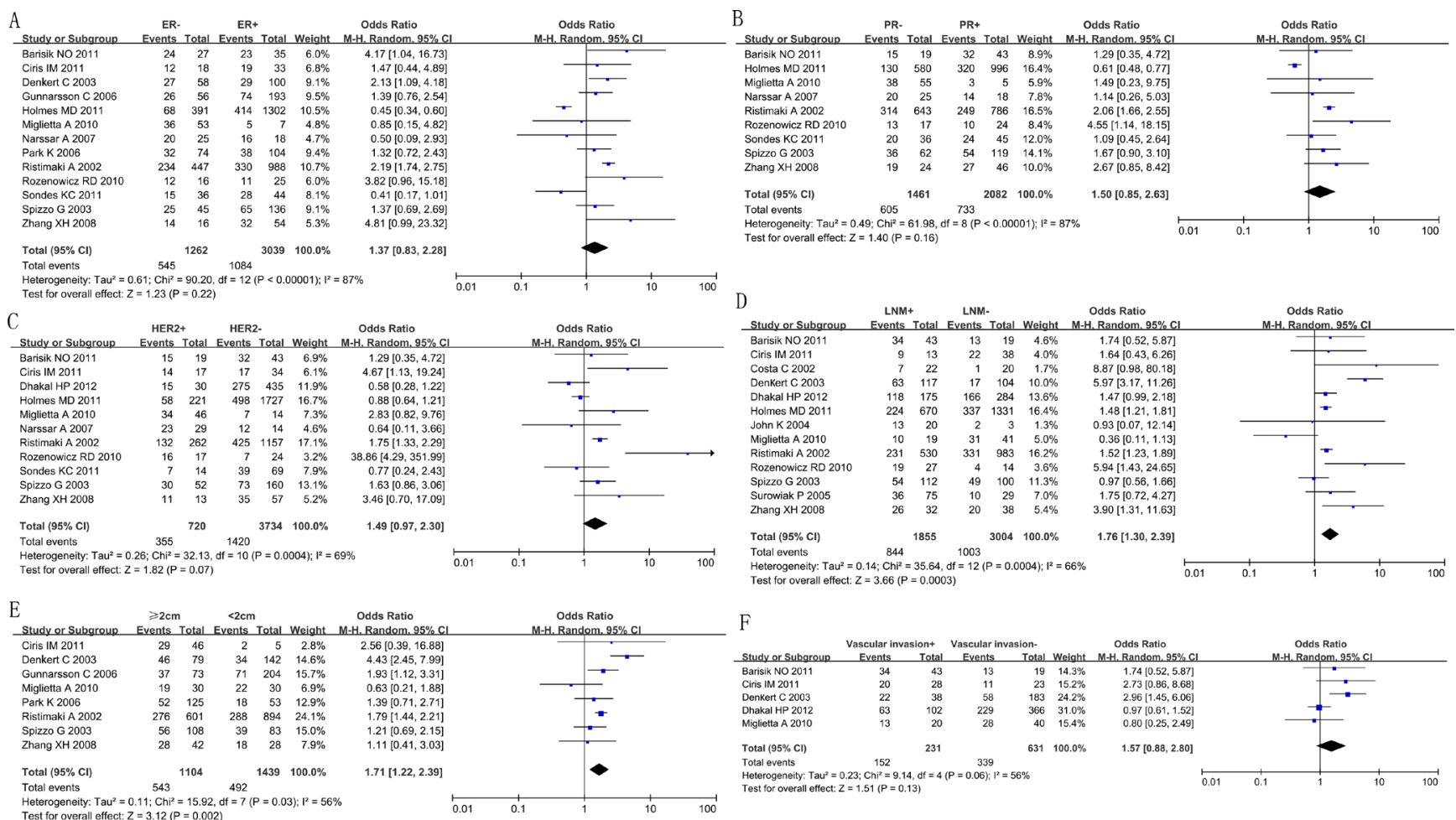

Figure 3: Forest plots of studies evaluating the association between COX-2 and clinical parameters in breast cancer with random effect model. (A): ER status (negative vs. positive); (B): PR status (negative vs. positive); (C): HER-2 status (positive vs. negative); (D): lymph node metastasis (present vs. absent); (E): tumor size $(\geq 2 \mathrm{~cm}$ vs. $<2 \mathrm{~cm}$ ); (F): vascular invasion (present vs. absent). 
Table 3: The assessment of the risk of bias in each enrolled study using the newcastle-Ottawa scale (NOS)

\begin{tabular}{|c|c|c|c|c|c|c|c|c|c|c|}
\hline \multirow{2}{*}{$\begin{array}{l}\text { Study } \\
\text { [ref] }\end{array}$} & \multicolumn{4}{|c|}{ Selection (0-4) } & \multicolumn{2}{|c|}{$\begin{array}{c}\text { Comparability } \\
(0-2)\end{array}$} & \multicolumn{3}{|c|}{ Outcome (0-3) } & \multirow{2}{*}{$\begin{array}{c}\text { Total scale } \\
\text { (NOS) }\end{array}$} \\
\hline & REC & SNEC & $\mathbf{A E}$ & DO & SC & $\mathbf{A F}$ & AO & $\mathbf{F U}$ & $\mathbf{A F U}$ & \\
\hline Costa C [11] & 1 & 0 & 1 & 1 & 1 & 1 & 1 & 0 & 1 & 7 \\
\hline Ristimaki A [12] & 1 & 1 & 1 & 0 & 1 & 1 & 0 & 0 & 0 & 5 \\
\hline Denkert C [13] & 1 & 1 & 1 & 1 & 1 & 1 & 1 & 0 & 1 & 8 \\
\hline Spizzo G [14] & 1 & 1 & 1 & 1 & 0 & 1 & 1 & 1 & 1 & 8 \\
\hline Wulfing P [15] & 1 & 1 & 1 & 1 & 0 & 0 & 1 & 1 & 1 & 7 \\
\hline John K [16] & 1 & 0 & 1 & 1 & 1 & 1 & 0 & 1 & 1 & 7 \\
\hline Surowiak P [17] & 1 & 0 & 1 & 1 & 1 & 1 & 1 & 1 & 1 & 8 \\
\hline Gunnarsson C [18] & 1 & 1 & 1 & 0 & 1 & 1 & 0 & 0 & 0 & 5 \\
\hline Park K [19] & 1 & 1 & 1 & 1 & 1 & 0 & 1 & 0 & 1 & 7 \\
\hline Narssar A [20] & 1 & 1 & 1 & 0 & 1 & 1 & 0 & 0 & 0 & 5 \\
\hline Zerkowski MP [21] & 1 & 1 & 1 & 1 & 1 & 1 & 0 & 1 & 1 & 8 \\
\hline Zhang XH [22] & 1 & 1 & 1 & 0 & 1 & 1 & 0 & 0 & 0 & 5 \\
\hline Glynn SA [23] & 1 & 1 & 1 & 1 & 1 & 0 & 1 & 1 & 1 & 8 \\
\hline Miglietta A [24] & 1 & 1 & 1 & 0 & 1 & 1 & 0 & 0 & 0 & 5 \\
\hline Rozenowicz RD [25] & 1 & 1 & 1 & 0 & 1 & 1 & 0 & 0 & 0 & 5 \\
\hline Barisik NO [26] & 1 & 1 & 1 & 0 & 1 & 1 & 0 & 0 & 0 & 5 \\
\hline Ciris IM [27] & 1 & 1 & 1 & 0 & 1 & 1 & 0 & 0 & 0 & 5 \\
\hline Holmes MD [28] & 1 & 1 & 1 & 1 & 1 & 0 & 1 & 1 & 1 & 8 \\
\hline Sondes KC [29] & 1 & 0 & 1 & 1 & 1 & 1 & 0 & 1 & 1 & 7 \\
\hline Dhakal HP [30] & 1 & 1 & 1 & 0 & 1 & 1 & 0 & 0 & 0 & 5 \\
\hline Kargi A [31] & 1 & 1 & 1 & 0 & 1 & 1 & 0 & 0 & 1 & 6 \\
\hline
\end{tabular}

REC: representativeness of the exposed cohort; SNEC: selection of the nonexposed cohort; AE: ascertainment of exposure; DO: demonstration that outcome of interest was not present at start of study; SC: study controls for age, sex; AF: study controls for any additional factors (chemoradiotherapy, curative resection); AO: assessment of outcome; FU: follow-up long enough (36 Months) for outcomes to occur; AFU: adequacy of follow-up of cohorts ( $\geq 90 \%)$. " 1 " means that the study is satisfied the item and " 0 " means the opposite situation.

performed on the eligible studies. The enrolled studies were sequentially omitted to investigate whether any single study could have an influence on the pooled OS or DFS. The results showed that the stable overall HR was found to be not dominantly influenced by each individual study.

\section{DISCUSSION}

Since the 1980s, accumulating studies have showed that long-term treatment with non-steroidal antiinflammatory drugs (NSAIDs) may lower the incidence of breast cancer development [32]. In vitro cell line researches suggest that NSAIDs and selective COX2 inhibitors impede breast cancer cell growth [33-35]. Numerous in vivo animal experiments clearly indicate that high COX-2 expression is correlated to the genesis of mammary tumors that are sensitive to treatment with non-selective and selective COX-2 inhibitors [36, 37]. Recently, combining specific COX-2 inhibitors with conventional chemotherapy as a novel approach brings about some promising results in the field of $\mathrm{BC}$ treatment $[38,39]$. Although the therapeutic effect of COX-2 is generally accepeted, evidence about the prognostic role of COX-2 in breast cancer is limited. As far as we know, this present meta-analysis is the first study to systematically assess the relationship between COX-2 overexpression and clinicopathological features/prognoses in $\mathrm{BC}$ patients.

The present meta-analysis of 21 clinical studies, which detected the COX-2 expression in $\mathrm{BC}$ tissue samples, indicated that elevated COX-2 expression was significantly associated with decreased 5-year OS and DFS rates of patients with mammary tumor. Additionally, when the clinicopathologic features were considered, the combined odds ratio(OR) was found to be significantly 
associated with bigger tumor size and positive lymph node metastasis of breast carcinoma. Based on these results, COX-2 might function as a valuable prognostic biomarker of breast carcinoma and provide a rationale for antitumor therapy on BC patients in future clinical trials.

Although our results showed that COX-2 acted to drive tumor growth and axillary node metastases of breast cancer, the mechanisms responsible for the above association remained unclear. There is some evidence that COX-2 is involved in the synthesis of prostaglandins, such as PGE1, PGE2 and PGI2 [40]. Interestingly, COX-2 and its products participate in the proliferation of mammary epithelial cells as they affect the synthesis process of DNA. Thus, the suppression of COX-2 with selective COX-2 inhibitors in breast cancer cells causes cell cycle G1 arrest and reduces the number of cells in $\mathrm{S}$ and $\mathrm{G} 2 / \mathrm{M}$ phase, thereby inhibiting cell mitosis [41, 42]. Recently, new perspectives on COX-2 promoting tumor growth showed that the proliferation signals of BC cells were stimulated by estrogen acting upon the estrogen receptor(ER). ER induces c-Myb expression which in turn may stimulate COX-2, making estrogen more readily available in the cell. This positive feedback further promotes tumor growth. In addition, the molecular mechanisms underlying the impact of COX-2 on $\mathrm{BC}$ metastasis to regional lymph node remain largely unknown. The present studies indicate that COX-2 mediates VEGF-C expression depending on the endogenous PGE2 pathway regulated by the EP1/EP4 receptors, which may contribute to tumor lymphangiogenesis and lymph node metastasis [22, 43]. All the same, more studies are required to analyze the specific molecular mechanism of COX-2 overexpression facilitating breast cancer growth and metastasis.

Although our results are promising, our meta analysis has several limitations. Firstly, the sample size of most enrolled studies was relatively small. Secondly, the high variability for COX-2 protein expression reported by different authors could partly be attributed to the inconsistent scoring methods, protocol of staining and cut-off points for COX-2 immunoexpression. Thirdly, few

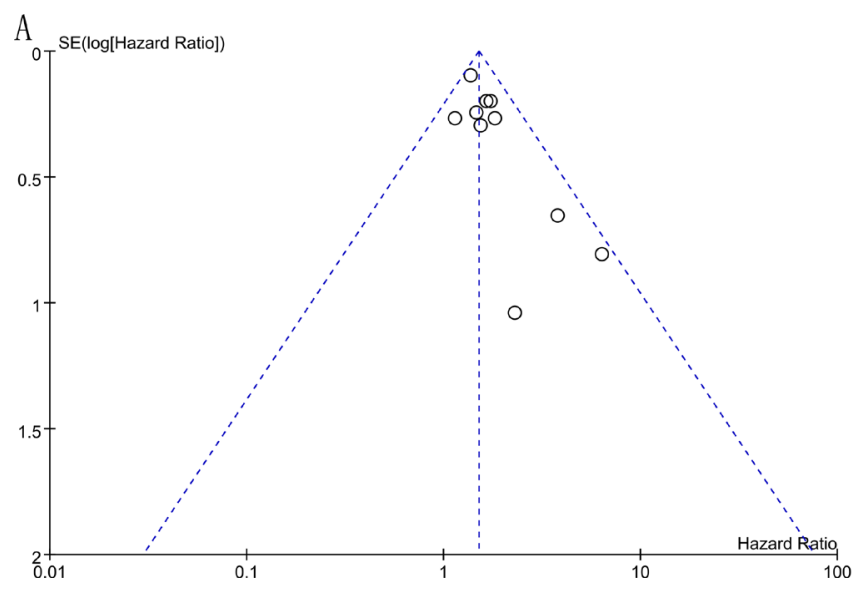

studies explored the COX-2 expression in Asian population, which might bring out a certain publication bias. Fourthly, most of the enrolled studies were retrospective studies rather than randomized prospective studies.

In conclusion, the present meta-analysis suggest that COX-2 up-regulation can predict an unfavorable prognosis of BC patients. Our results also indicate an association of COX-2 overexpression with clinicopathological features such as bigger tumor size and lymph node metastasis. More multicentre and prospective studies are needed to clarify the clinical relevance and precise molecular explanation for the abnormal expression of $\mathrm{COX}-2$.

\section{MATERIALS AND METHODS}

\section{Search strategy and study selection}

The electronic databases PubMed, EMBASE, Web of Science, the Ovid Database and Grey literature were searched for studies to include in this meta-analysis up to May 31st, 2016. The key words were searched as follows: "breast cancer" or "breast carcinoma" or "mammary gland cancer" or "breast tumor" or "breast tumour" or "breast neoplasm", "COX-2" or "Cyclooxygenase-2", and "prognosis" or "survival" or "outcome".

To be eligible for inclusion in this meta-analysis, a study must meet the following criteria: (1) the correlation between COX-2 expression with $\mathrm{BC}$ patients' survival (ie, overall survival [OS] and/or disease free survival [DFS]) was investigated; (2) the expression of COX-2 was measured by immunohistochemistry (IHC)/Tissue microarray(TMA) method in the primary $\mathrm{BC}$ specimen; (3) the correlation between COX-2 and clinicopathological features of breast cancer was described; (4) all selected $\mathrm{BC}$ patients were pathologically confirmed; and (5) the median follow-up period was no less than 24 months. All candidate manuscripts were carefully read by two independent authors (XF and $\mathrm{JHC}$ ). To reach a consensus, disagreements on conflicting results were resolved between the two authors.

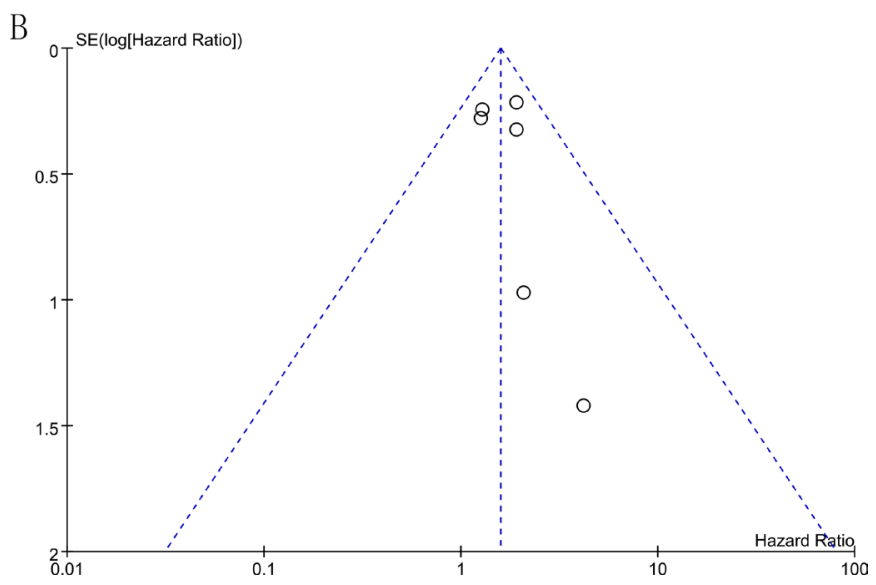

Figure 4: Funnel plots for all of the included studies reported with OS (A) and DFS (B). 
The exclusion criteria were as follows: (1) nonEnglish articles; (2) non-human studies; (3) case reports, review articles, or letters; (4) duplicate publication; (5) with no more than 20 eligible BC patients; and (6) with insufficient data to calculate the hazard ratios(HR) and its $95 \%$ confidence interval $(95 \% \mathrm{CI})$, or the Kaplan-Meier curve in the article could not be extracted.

\section{Data extraction}

All relevant articles included were screened and assessed independently by two investigators (XF and JHC). To identify high-quality studies, each publication was scored based on the New-castle-Ottawa (NOS) Quality Assessment Scale [44]. Study with a score of 6 or higher was considered as a high quality study. Information was carefully extracted from the full publications, including the following items: first author, number of patients, year of publication, country of origin, detection method, cutoff value, antibody for COX-2 staining, positive COX-2 expression, analysis method, hazard ratio (HR) for survival (OS and/or DFS), follow-up time, and quality assessment. To get the survival data that were not reported by the authors, we digitized and extracted the data from the Kaplan-Meier curves in the articles using the software designed by Jayne F Tierney and Matthew R Sydes [45].

\section{Statistical methods}

According to the guidelines proposed by the MetaAnalysis of Observational Studies in Epidemiology group (MOOSE) [46], enrolled studies were divided into two groups for analysis: those with data regarding OS and DFS. Hazard ratios (HRs) and 95\% confidence intervals (CIs) were used to combine as the effective value. For the pooled analysis of the correlation between COX-2 overexpression and clinicopathological features, odds ratios (ORs) and 95\% CIs were combined to estimate the effect. $I^{2}$ and $Q$ tests were performed to calculate the heterogeneity of the individual HRs/ORs. A probability value of $P<0.1$ and $I^{2} \geq 50 \%$ indicated the existence of significant heterogeneity. A fixed or random effect model was used depending on the heterogeneity analysis. For these analyses, $P<0.05$ was considered to indicate significance. Publication bias was assessed using Begg's funnel plot and Egger's test. All of the calculations were performed by Review Manager version 5.3 (Cochrane Collaboration, Oxford, England).

\section{ACKNOWLEDGMENTS}

Feng Xu, Mengxin Li and Hongchuan Jiang designed the study and wrote the manuscript. Chao Zhang, Jianxiu Cui, Jun Liu and Jie Li collected the relevant papers and data. Feng Xu, Chao Zhang and Hongchuan Jiang analyzed the data. All authors reviewed the manuscript.

\section{CONFLICTS OF INTEREST}

The authors have declared no conflicts of interest.

\section{GRANT SUPPORT}

This study was supported by grants from the project of the Science and Technology Commission of Beijing Municipality (No. D16110000816002).

\section{REFERENCES}

1. Siegel RL, Miller KD, Jemal A. Cancer statistics, 2015. CA Cancer J Clin. 2015; 65:5-29.

2. Sturgeon CM, Duffy MJ, Stenman UH, Lilja H, Brunner N, Chan DW, Babaian R, Bast RC, Jr., Dowell B, Esteva FJ, Haglund C, Harbeck N, et al. National Academy of Clinical Biochemistry laboratory medicine practice guidelines for use of tumor markers in testicular, prostate, colorectal, breast, and ovarian cancers. Clin Chem. 2008; 54:e11-79.

3. Simmons DL, Botting RM, Hla T. Cyclooxygenase isozymes: the biology of prostaglandin synthesis and inhibition. Pharmacol Rev. 2004; 56:387-437.

4. McFadden DW, Riggs DR, Jackson BJ, Cunningham C. Additive effects of Cox-1 and Cox-2 inhibition on breast cancer in vitro. Int J Oncol. 2006; 29:1019-1023.

5. Appleby SB, Ristimaki A, Neilson K, Narko K, Hla T. Structure of the human cyclo-oxygenase-2 gene. Biochem J. 1994; 302:723-727.

6. Yokouchi H, Kanazawa K. Revisiting the role of COX-2 inhibitor for non-small cell lung cancer. Transl Lung Cancer Res. 2015; 4:660-664.

7. Song S, Guha S, Liu K, Buttar NS, Bresalier RS. COX-2 induction by unconjugated bile acids involves reactive oxygen species-mediated signalling pathways in Barrett's oesophagus and oesophageal adenocarcinoma. Gut. 2007; 56:1512-1521.

8. Wu QB, Sun GP. Expression of COX-2 and HER-2 in colorectal cancer and their correlation. World $\mathrm{J}$ Gastroenterol. 2015; 21:6206-6214.

9. Kang CM, Kim HK, Kim H, Lee WJ. Cyclooxygenase-2 (COX-2) expression in solid pseudopapillary tumor of the pancreas: a pilot study. Pancreas. 2011; 40:159-161.

10. Arun B, Goss P. The role of COX-2 inhibition in breast cancer treatment and prevention. Semin Oncol. 2004; 31:22-29.

11. Costa C, Soares R, Reis-Filho JS, Leitao D, Amendoeira I, Schmitt FC. Cyclo-oxygenase 2 expression is associated with angiogenesis and lymph node metastasis in human breast cancer. J Clin Pathol. 2002; 55:429-434.

12. Ristimaki A, Sivula A, Lundin J, Lundin M, Salminen T, Haglund C, Joensuu H, Isola J. Prognostic significance of elevated cyclooxygenase- 2 expression in breast cancer. Cancer Res. 2002; 62:632-635.

13. Denkert C, Winzer KJ, Muller BM, Weichert W, Pest S, Kobel M, Kristiansen G, Reles A, Siegert A, Guski H, 
Hauptmann S. Elevated expression of cyclooxygenase-2 is a negative prognostic factor for disease free survival and overall survival in patients with breast carcinoma. Cancer. 2003; 97:2978-2987.

14. Spizzo G, Gastl G, Wolf D, Gunsilius E, Steurer M, Fong D, Amberger A, Margreiter R, Obrist P. Correlation of COX-2 and Ep-CAM overexpression in human invasive breast cancer and its impact on survival. Br J Cancer. 2003; 88:574-578.

15. Wulfing $\mathrm{P}$, Diallo R, Muller C, Wulfing C, Poremba C, Heinecke A, Rody A, Greb RR, Bocker W, Kiesel L. Analysis of cyclooxygenase-2 expression in human breast cancer: high throughput tissue microarray analysis. J Cancer Res Clin Oncol. 2003; 129:375-382.

16. O'Connor JK, Avent J, Lee RJ, Fischbach J, Gaffney DK. Cyclooxygenase-2 expression correlates with diminished survival in invasive breast cancer treated with mastectomy and radiotherapy. Int J Radiat Oncol Biol Phys. 2004; 58:1034-1040.

17. Surowiak P, Materna V, Matkowski R, Szczuraszek K, Kornafel J, Wojnar A, Pudelko M, Dietel M, Denkert C, Zabel M, Lage H. Relationship between the expression of cyclooxygenase 2 and MDR1/P-glycoprotein in invasive breast cancers and their prognostic significance. Breast Cancer Res. 2005; 7:R862-870.

18. Gunnarsson C, Jansson A, Holmlund B, Ferraud L, Nordenskjold B, Rutqvist LE, Skoog L, Stal O. Expression of COX-2 and steroid converting enzymes in breast cancer. Oncol Rep. 2006; 16:219-224.

19. Park K, Han S, Shin E, Kim HJ, Kim JY. Cox-2 expression on tissue microarray of breast cancer. Eur J Surg Oncol. 2006; 32:1093-1096.

20. Nassar A, Radhakrishnan A, Cabrero IA, Cotsonis G, Cohen C. COX-2 expression in invasive breast cancer: correlation with prognostic parameters and outcome. Appl Immunohistochem Mol Morphol. 2007; 15:255-259.

21. Zerkowski MP, Camp RL, Burtness BA, Rimm DL, Chung GG. Quantitative analysis of breast cancer tissue microarrays shows high cox-2 expression is associated with poor outcome. Cancer Invest. 2007; 25:19-26.

22. Zhang XH, Huang DP, Guo GL, Chen GR, Zhang HX, Wan L, Chen SY. Coexpression of VEGF-C and COX-2 and its association with lymphangiogenesis in human breast cancer. BMC cancer. 2008; 8:4.

23. Glynn SA, Prueitt RL, Ridnour LA, Boersma BJ, Dorsey TM, Wink DA, Goodman JE, Yfantis HG, Lee DH, Ambs S. COX-2 activation is associated with Akt phosphorylation and poor survival in ER-negative, HER2positive breast cancer. BMC cancer. 2010; 10:626.

24. Miglietta A, Toselli M, Ravarino N, Vencia W, Chiecchio A, Bozzo F, Motta M, Torchio B, Bocca C. COX-2 expression in human breast carcinomas: correlation with clinicopathological features and prognostic molecular markers. Expert Opin Ther Targets. 2010; 14:655-664.
25. Rozenowicz Rde L, Santos RE, Silva MA, Rodrigues FF, Oliveira AL, Ulson LB, Oliveira VM, Aoki T. Cox-2 and its association with prognostic factors and response to primary chemotherapy in patients with breast cancer. Rev Col Bras Cir. 2010; 37:323-327.

26. Barisik NO, Keser SH, Gul AE, Sensu S, Kandemir NO, Kucuk HF, Gumus M, Karadayi N. The value of COX-2 expression in the prognostic parameters of invasive ductal carcinoma of the breast. Med Oncol. 2011; 28:703-708.

27. Ciris IM, Bozkurt KK, Baspinar S, Kapucuoglu FN. Immunohistochemical COX-2 overexpression correlates with HER-2/neu overexpression in invasive breast carcinomas: a pilot study. Pathol Res Pract. 2011; 207:182-187.

28. Holmes MD, Chen WY, Schnitt SJ, Collins L, Colditz GA, Hankinson SE, Tamimi RM. COX-2 expression predicts worse breast cancer prognosis and does not modify the association with aspirin. Breast Cancer Res Treat. 2011; 130:657-662.

29. Karray-Chouayekh S, Trifa F, Khabir A, Boujelbene N, Sellami-Boudawara T, Daoud J, Frikha M, Gargouri A, Mokdad-Gargouri R. Methylation status and overexpression of COX-2 in Tunisian patients with ductal invasive breast carcinoma. Tumour Biol. 2011; 32:461-468.

30. Dhakal HP, Naume B, Synnestvedt M, Borgen E, Kaaresen R, Schlichting E, Wiedswang G, Bassarova A, Holm R, Giercksky KE, Nesland JM. Expression of cyclooxygenase-2 in invasive breast carcinomas and its prognostic impact. Histol Histopathol. 2012; 27:1315-1325.

31. Kargi A, Uysal M, Bozcuk H, Coskun HS, Savas B, Ozdogan M. The importance of COX-2 expression as prognostic factor in early breast cancer. J BUON. 2013; 18:579-584.

32. Rolland PH, Martin PM, Jacquemier J, Rolland AM, Toga M. Prostaglandin in human breast cancer: Evidence suggesting that an elevated prostaglandin production is a marker of high metastatic potential for neoplastic cells. J Natl Cancer Inst. 1980; 64:1061-1070.

33. Kim MJ, Kim HS, Lee SH, Yang Y, Lee MS, Lim JS. NDRG2 controls COX-2/PGE-mediated breast cancer cell migration and invasion. Mol Cells. 2014; 37:759-765.

34. Singh B, Irving LR, Tai K, Lucci A. Overexpression of COX-2 in celecoxib-resistant breast cancer cell lines. The J Surg Res. 2010; 163:235-243.

35. Singh B, Cook KR, Vincent L, Hall CS, Martin C, Lucci A. Role of COX-2 in tumorospheres derived from a breast cancer cell line. J Surg Res. 2011; 168:e39-49.

36. Carter CA, Milholland RJ, Shea W, Ip MM. Effect of the prostaglandin synthetase inhibitor indomethacin on 7,12-dimethylbenz(a)anthracene-induced mammary tumorigenesis in rats fed different levels of fat. Cancer Res. 1983; 43:3559-3562.

37. McCormick DL, Madigan MJ, Moon RC. Modulation of rat mammary carcinogenesis by indomethacin. Cancer Res. 1985; 45:1803-1808. 
38. Falandry C, Canney PA, Freyer G, Dirix LY. Role of combination therapy with aromatase and cyclooxygenase-2 inhibitors in patients with metastatic breast cancer. Ann Oncol. 2009; 20:615-620.

39. Falandry C, Debled M, Bachelot T, Delozier T, Cretin J, Romestaing P, Mille D, You B, Mauriac L, PujadeLauraine E, Freyer G. Celecoxib and exemestane versus placebo and exemestane in postmenopausal metastatic breast cancer patients: a double-blind phase III GINECO study. Breast Cancer Res Treat. 2009; 116:501-508.

40. Goin M, Pignataro O, Jimenez de Asua L. Early cell cycle diacylglycerol (DAG) content and protein kinase C (PKC) activity enhancement potentiates prostaglandin $\mathrm{F} 2$ alpha (PGF2 alpha) induced mitogenesis in Swiss 3T3 cells. FEBS Lett. 1993; 316:68-72.

41. Lim SC. Role of COX-2, VEGF and cyclin D1 in mammary infiltrating duct carcinoma. Oncol Rep. 2003; 10:1241-1249.

42. Yoshinaka R, Shibata MA, Morimoto J, Tanigawa N, Otsuki Y. COX-2 inhibitor celecoxib suppresses tumor growth and lung metastasis of a murine mammary cancer. Anticancer Res. 2006; 26(6B):4245-4254.

43. Liu H, Yang Y, Xiao J, Lv Y, Liu Y, Yang H, Zhao L. COX2-mediated regulation of VEGF-C in association with lymphangiogenesis and lymph node metastasis in lung cancer. Anat Rec (Hoboken). 2010; 293:1838-1846.

44. Stang A. Critical evaluation of the Newcastle-Ottawa scale for the assessment of the quality of nonrandomized studies in meta-analyses. Eur J Epidemiol. 2010; 25:603-605.

45. Tierney JF, Stewart LA, Ghersi D, Burdett S, Sydes MR. Practical methods for incorporating summary time-to-event data into meta-analysis. Trials. 2007; 8:16.

46. Stroup DF, Berlin JA, Morton SC, Olkin I, Williamson GD, Rennie D, Moher D, Becker BJ, Sipe TA, Thacker SB. Meta-analysis of observational studies in epidemiology: a proposal for reporting. Meta-analysis Of Observational Studies in Epidemiology (MOOSE) group. Jama. 2000; 283:2008-2012. 